\title{
A Cashless Policy and Economic Development in Nigeria
}

DOI: https://doi.org/10.47175/rissj.v1i2.45

\section{| Fatogun Olukunle Ibukun ${ }^{1, *}$ | Ajao Chukwudumebi Cynthia ${ }^{2}$ |}

\author{
${ }^{1,2}$ Accountancy Department, \\ Federal Polytechnic llaro, \\ Ogun State. Nigeria \\ 1Ibkolad@gmail.com \\ 22dumebi_okeleke@yahoo.com
}

\begin{abstract}
A cashless economy is an environment in which money is spent without being physically carried from one place to another. It is meant to be an economic setting where services and goods are paid for via electronic which includes credit cards, bank transfer and Cheques, with no bill or money handed from one person to another. The cashless policy was introduced in January 2012, the robust interest which the policy has generated is surprising considering the effects on the business environment and particularly lives of ordinary Nigerians. The study showed that cashless policy reduces the movement of cash through usage of ATM, fund transfer, mobile banking. It helps financial transactions to be done without delay, it reduces money laundering. The study indicated that there is a very weak positive relationship between cash movement, joint effect of delivery of financial transactions and cashless policy $(R=0.245)$ and the model is not significant. However, for the relationship between internet availability, cashless policy and cash movement, the relationship between cash movement, the joint effect of internet availability and cashless policy is also weak $(R=0.295)$. The model is also significant. The policy is faced with challenges ranging from erratic power supply, electronic fraud, lack of adequate sensitization, poor internet services, high rate of illiteracy and computerization. The benefits include but not limited to reduction in revenue leakages, it helps to reduce cash related crimes, the cost of handling cash is reduced to the barest minimum KEYWORDS

cashless policy; economic development; electronic
\end{abstract}

\section{INTRODUCTION}

Cashless policy is the regulation made by the central bank of Nigeria to simply move from a gradual physical movement of payment system with the use of a systematic adoption of other non physical cash mode of payments in settlement of all types of transactions including commercial, personal, local and international trade. The policy also aimed at reducing the cost of banking services and improving the effectiveness of monetary policy in managing inflation and driving economic development (CBN website 2011).

The most outstanding cashless banking channels over the world are mobile banking, internet banking, electronic card implants, points of sales terminals, telephone banking and automated teller machine (Odumeru 2013). For clarification purposes the introduction of cashless policy in Nigeria would moderate the cost of each management, reduces lending rate, encourage the use of electronic payment, individuals and organizations will convert paper money to bank deposits. It also helps to modernize the payments, stimulates and develops the payment system while also curbing the criminality associated with travelling around with lots of physical cash. 
Despite the benefits associated with the policy, there have been some constraints and challenges confronting the policy, these include: the infrastructures which have not been good enough giving way to ineffectiveness. The technology access for the transaction are not effective as system failure are experienced most times at point of transactions leaving individuals with no choice than to deal with cash directly. Many are of the opinion that the cash limit set by the central bank is too low and also query how the bench mark was arrived at.

This study will help to analyse the cost and benefits of payment instruments involved in the shift toward a cashless society. Based on the above, the central bank of Nigeria introduced a policy which stipulates that no individuals and businesses will be allowed to withdraw above Five Hundred Thousand Naira (N500,000) and Three Million Naira $(\mathrm{N} 3,000,000)$ and any amount that exceeds the stipulated limit attracts a cash handling charge of 3\% for individuals and 5\% for business organizations on daily cash withdrawal, where the banks aim at reducing (not eliminating) the amount of physical cash (Notes) circulating the economy. Moreover, a third party cheque above One hundred and fifty thousand naira $(\mathrm{N} 150,000)$ shall not be eligible for encashment across the counter. The cheque serves as income for banks.

\section{REVIEW OF LITERATURE}

Cashless economy is one that has been discussed in literature as found in pre credit economy where monetary policy (is conceived) without money. Cashless economy is an economic setting where goods and services are brought and paid for through electronic media (Okoye and Ejiofor 2013).

The Central Bank of Nigeria (CBN) has diverse programmes which help to put financial system in a better position and also contribute to the achievement of the country. Years back the Automated Teller Machine was introduced into the country with skepticism, now it has gotten a wider acceptance from the populace due to the awareness of its benefits. Customers now use alternative payment channels, cheque clearance, cards, Point of Sales (POS), mobile banking amongst others (Ogede 2009).

Cashless economy is a financial environment that minimizes the uses of physical cash by providing alternative means for making payments (Alilonu, 2012).

For clarification purposes, cashless policy was built on the precepts that the economy will be in a way that cash movement within the country will be reduced to card carrying, use of POS machine, use of cheque, mobile banking, and direct transfer of funds from one means to another, through the application of computer technology. Hogarth.(2008), used diffusion innovation theory to investigate the customer payment choices, paper, plastic or electrons. It was found that increase in income and education also elicit a positive effect on adoption of electronic banking regardless of technology.

Omotunde, Tunmibi and John-Dewole; (2013) studies the influence of cashless policy in Nigeria, responses from the respondents showed that the policy will increase employment, reduce cash related robbery by reducing risk of carrying cash, and it will also help to reduce corruption and at the end it will attract foreign investors to the country.

According to Nweke (2012) cashless economy is an economy where the physical cash circulating in the economy is minimized. While other forms of payment especially electric based payments are utilized, that is a cash based payment system and electronic payment systems.

In addition, the policy also helps to reduce branch network and incidents of armed robbery. This helps to impact on the security of the people because there is responsiveness of the banking services, which means no individual needs to waste time on queues in the 
bank to withdraw or deposit money. This saves time and increases productivity hours (CBN: 2012, guidelines on cashless policy).

Woodford (2013) describes cashless economy as "one that is assumed to be no transaction frictions which can be reduced through the use of money balances and accordingly provide a reason for holding such balances, even when they earn rate of return.

It should be noted that as of today there are several series of cashless transactions that are taking place in Nigeria. There are different electronic payment channels, automated teller machines (ATM), Points of Sales terminals, mobile voice web, and inter bank branch.

Internet banking: it involves conducting banking transactions on the internet using electronic tools such as computer without customer having to visit the bank. It is a product that enables the bank to leverage on the internet.

Point of Sale (POS) Terminals: This is location where a transaction occurs. The POS terminal is referred to as the hardware and software used for checkout equivalent to an electronic cash register. It manages the selling process by a sales person accessible interface, at the end it allows for creation and printing of receipts.

Automated Teller Machine Card: The Automated Teller Machine was designed to provide mobile payment service, breakdown the traditional barriers hindering financial inclusion of millions of Nigerians and bring about low cost, secured and convenient financial services to urban, semi urban and rural areas across the country. It is a widely acceptable means of settling financial transactions and obligations, a computerized device that provide the customers of a financial institution with access to financial transaction without a need of assistance from a bank official.

\section{Information Technology and Cashless Economy}

Information Technology plays an important role in bringing about sustainable development in every nation, without an optimal use of technology no country can attain socio economic development. One major use of a technology is influenced directly or indirectly by the users behavioural intentions, altitude, perceived usefulness of the system and perceived ease of the system. Transition to a cashless economy will raise a lot of security issue in our financial institution. IT professional should be charged to provide a robust IT support.

\section{Impact Of Cashless Policy And Economic Development}

These are areas which the cashless economy will enhance the quality of life, they are:

- Faster Transaction: This is the reduction on queue at point of sale or point of payment.

- Increased Sale/ Cash Collection: The policy enhanced increased sales as well as cash collection because the time spent in collecting, counting and sorting of cash collected is eliminated.

- Customer Satisfaction: it increases customers satisfaction, easier documentation and transaction tracking hence increase banks customer relationship. The cashless policy was introduced to drive development and modernization of Nigerian's payment system. It drives financial inclusion by providing more efficient transaction options.

- It improves the effectiveness of monetary policy in managing inflation (CBN website 2011). 


\section{Benefits of the Cashless Policy in Nigeria}

Some of the benefits of the policy are highlighted below:

- Comfortability /convenience: With cashless policy there will be increased convenience and cheaper access to banking services as most people would have their transaction done through the usage of the cell phone readily available in their wallets.

- Increased personal security: Imagine carrying no cash in your pocket, no more pick pocketing, the risk associated with physical cash is eliminated. Thefts and risk associated with use of physical cash which arises from burglaries and financial losses and fire outbreaks are eliminated.

- Reduction in handling and transportation cost: If all monetary transactions were done electronically, there would be no need to move around large sum in expensive high level security vehicles, high operational cost will be eliminated drastically hence resulting in savings for both public and private entities.

- Boost to GDP: Individual will be able to control reckless spending and people will be forced to convert their savings into consumption or investment. This will boost the GDP, it will also help to facilitate effectiveness of monetary policy and check inflation hence it creates more employment in the financial sector.

- Enhance the tax base: As all transactions in the economy could now be traced by the government, there is increased tax collection and reduction in revenue leakage.

- Utility Bill: Through the system, uses can also pay utility bills, School Fees, Hotel bookings, house rent by using a mobile phone device (Eromosele and Obinna, 2012).

- Reduction in corruption: It helps to reduce illicit activities, corruption and sharp practices, reduction in money laundering and also help to checkmate terrorist financing thereby leading to economic growth.

- Electric payment: Electronic will help business owners to grow their customer base and resource pool far beyond limitations of their immediate geographical area. It is cost effective when compared to paper based payment system.

\section{Challenges of the Cashless Economy}

- Extensive power out: This is an event that disrupts electronic transactions and efficient e-payment system. This has a negative effect on the success of the cashless policy.

- Level of illiteracy/Computerization/Inadequate sensitization: The rate of illiteracy is very high where most business men prefer to keep the money in their own vault rather than the bank. The policy also requires use of technology which is affected by the rate of illiteracy.

- Fraudulent practices: The policy is technology driven hence fraudsters can take advantage of any security lapses to perpetrate fraud.

- Inadequate infrastructure: There is inadequate facilities which resulted in long queues at the ATM points. Most time there is breakdown of the ATM.

- System failure: This occurs most times at the ATM point when withdrawals is about to be made after inserting the card, the machine just went off,in the process the customer's account would have been debited. 


\section{RESEARCH METHODS}

Regression analysis (Using OLS method) was used to examine the impact of cashless policy on cash movement through the usage of ATM, fund transfer, internet availability and to determine whether cashless policy has impact on delivery of financial transactions on economic development in Nigeria.

\section{Research Hypothesis}

The hypotheses below were tested as a means of carrying out the objective of the study. Ho i: There is no significant relationship between cashless policy and cash movement Ho ii: There is no significant relationship between delivery of financial transaction and cash movement

Ho iii: There is no significant relationship between internet availability and cash movement

\section{RESULT AND DISCUSSION}

\section{Test of Hypotheses}

From table 1, which is the model summary table for relationship between the cashless policy, delivery of financial transactions and cash movement. The correlation coefficient $\mathrm{R}$ is 0.245 with coefficient of variation of 0.060 . This is an indication that there is a very weak positive relationship between joint effect of delivery of financial transactions, cash movement and cashless policy. It also further revealed that only $6 \%$ variation in cashless movement can be accounted for by the joint effect of cashless policy and delivery of financial transactions

Table 1. Model Summary

\begin{tabular}{|c|c|c|c|c|}
\hline Model & $\mathbf{R}$ & R Square & $\begin{array}{l}\text { Adjusted R } \\
\text { Square }\end{array}$ & $\begin{array}{l}\text { Std. Error of } \\
\text { the Estimate }\end{array}$ \\
\hline 1 & $.245^{\mathrm{a}}$ & .060 & .039 & 1.764 \\
\hline
\end{tabular}

The ANOVA table in table 2 gives $F$ value of 2.880 and sig value of 0.061 which is greater than 0.05 significance value. Hence the model is not adequate in relating cashless policy, cash movement and delivery of financial transactions. Moreover, none of the independent variable is significant (table 3), since the significant value of all the variables are greater than 0.05 (that is, cashless policy significant value is 0.463 and significant value for delivery of financial transactions is 0.089 ).

Table 2. ANOVA ${ }^{\mathrm{a}}$

\begin{tabular}{lllllll}
\hline Model & & Sum of Squares & Df & Mean Square & F & Sig. \\
\hline \multirow{3}{*}{1} & Regression & 17.924 & 2 & 8.962 & 2.880 & $.061^{\mathrm{b}}$ \\
& Residual & 280.033 & 90 & 3.111 & & \\
\cline { 2 - 7 } & Total & 297.957 & 92 & & & \\
\hline
\end{tabular}

a. Dependent Variable: CM

b. Predictors: (Constant), DFT, CP

Table 3. Coefficients ${ }^{\mathrm{a}}$

\begin{tabular}{lllllll}
\hline Model & & \multicolumn{2}{l}{ Unstandardized Coefficients } & $\begin{array}{l}\text { Standardized } \\
\text { Coefficients }\end{array}$ & t & \multirow{2}{*}{ Sig. } \\
\cline { 3 - 5 } & & B & Std. Error & Beta & \\
\hline \multirow{2}{*}{1} & (Constant) & 11.522 & 1.743 & & 6.612 & .000 \\
& CP & .080 & .109 & .084 & .737 & .463 \\
& DFT & .171 & .099 & .196 & 1.720 & .089 \\
\hline
\end{tabular}

a. Dependent Variable: CM 
From table 4, which is the model summary table for relationship between the cash movement, cashless policy and internet availability. The correlation coefficient $\mathrm{R}$ is 0.295 with coefficient of variation of 0.087 . This is an indication that there is a very weak positive relationship between joint effect of cash movement, cashless policy and internet availability. It also further revealed that only $8.7 \%$ variation in cash movement can be accounted for by the joint effect of cashless policy and internet availability.

Table 4. Model Summary

\begin{tabular}{|c|c|c|c|c|}
\hline Model & $\mathbf{R}$ & R Square & $\begin{array}{l}\text { Adjusted } \\
\text { Square }\end{array}$ & $\begin{array}{l}\text { R Std. Error of } \\
\text { the Estimate }\end{array}$ \\
\hline 1 & $.295^{\mathrm{a}}$ & .087 & .067 & 1.822 \\
\hline
\end{tabular}

Table 5: ANOVA $^{\mathrm{a}}$

\begin{tabular}{|c|c|c|c|c|c|c|}
\hline Model & & Sum of Squares & Df & Mean Square & $\mathbf{F}$ & Sig. \\
\hline \multirow{3}{*}{1} & Regression & 28.472 & 2 & 14.236 & 4.290 & $.017^{\mathrm{b}}$ \\
\hline & Residual & 298.646 & 90 & 3.318 & & \\
\hline & Total & 327.118 & 92 & & & \\
\hline
\end{tabular}

a. Dependent Variable: CM

b. Predictors: (Constant), INA, CP

The ANOVA table in table 5 gives $F$ value of 4.290 and sig value of 0.017 which is less than 0.05 significance value. Hence the model is adequate in relating cash movement, internet availability and cashless policy. Moreover, all the independent variables (table 6) are significant, since the significant value of all the independent variables are less than 0.05 (that is, cashless policy significant value is 0.049 and internet availability significant value is 0.019 ).

Then, the model can be specified as:

$\mathrm{CM}=10.082+0.203 \mathrm{CP}+0.207 \mathrm{INA}$

This implies that, if all internet availability remain constant, a unit increase in cashless policy will result in about $20.3 \%$ increase in cash movement. And also, a unit increase in internet availability will cause $20.7 \%$ increase in cash movement provided cashless policy remain constant.

Table 6. Coefficients ${ }^{\mathrm{a}}$

\begin{tabular}{lllllll}
\hline Model & & \multicolumn{2}{l}{ Unstandardized Coefficients } & $\begin{array}{l}\text { Standardized } \\
\text { Coefficients }\end{array}$ & t & Sig. \\
\cline { 3 - 5 } & & $\mathrm{B}$ & Std. Error & Beta & \\
\hline \multirow{2}{*}{$; 1$} & (Constant) & 10.082 & 2.250 & & 4.480 & .000 \\
& CP & .203 & .106 & .194 & 1.915 & .049 \\
& INA & .207 & .087 & .241 & 2.386 & .019 \\
\hline
\end{tabular}

\section{Where:}

CP.Cashless policy

CM.Cash movement

INA. Represent internet availability

\section{CONCLUSION}

Cashless economy policy reduces the amount of cash-based transactions to the bearest minimum. In Nigeria, the concept tries to discourage the idea of cash transactions. However, the introduction of electronic banking in Nigeria has a strong influence on the development of payment system. It involves commitment of huge amount of financial 
resources on computer technology, telecommunication facilities, internet services and regular supply of electricity. the policy in Nigeria has a lot of merits and costs to the society but the merits outweighs the costs in many ways.

\section{REFERENCES}

Ajayi, M., (2006). "Banking Sector Reforms and Banking Consolidation: Conceptual Framework", Bullion, Vol. 29, No. 2.

Ajayi, S.I. and Ojo, O.O. (2006). "Banking Sector Reforms and Banking Consolidation: Conceptual Framework", Bullion, vol. 29, No. 2, 2006. Vol. 1,Issue 2.(Canadian Journal of Accounting and Finance.

Akhalumeh and Ohiakha (2012) reported in Alawiye (2013) The Cashless Nigerian Project. Global Advanced Research Journal of Management and Business Studies. Vol. 2 No.1. 2013.

Alawiye, Adams A.A. (2013). The Cashless Nigerian Project, Global Advanced Research Journal of Management and Business Studies ISSN: 2315 - 5086) Vol. 2

Aremu, M.A. and Adeyemi, S.L. (2011). Small and Medium Scale Enterprises as a Survival Strategy for Employment Generation in Nigeria.www.ccsenet.org/jsd Journal of Sustainable Development.

Awosika, B.O. (1997). Evolving a National Framework for the Emergency of a Strong and Virile Small and Medium Scale Industry Sub-Sector in Nigeria. A Seminar Paper Presented at MAN House, November 5th p.3.

Al S. (1994). Identification, Privacy, Freedom and Guaranteed by the use by personal PCs for e-banking transactions' fortune magazine, June 27. Atarere \& Osemwegie-Ero. (2014). Int.J.Innovative Soc. Sc. \& Hum. Res. 2(2): 98-105.

Azeez, K., (2011). "Cyber Insecurity Threatens Nigeria Cashless Economy Drive". (Online)Available: http://www.nationalmirroronline.net/.../22594.htm.

Babalola, R. (2008). "E-payment: Towards a Cashless Economy", A Keynote address of the Finance Minister of State at CardExpo Africa Conference. (Online) Available:http://www.nigeriavillagesqyare.com.

Baridan, O. (1990). Research Methods in Administrative Sciences, Belk Publishers, Port Harcourt, pp44.

Baxter, J.I. (1993). "666 - The Mark of the Beast", (Online) Available:http://www.endtime/66 6.html.

Central Bank of Nigeria (2011). The Cashless Nigeria Project. Editorial feedback (2010). editor@thetruthseeker.co.uk Cashless.

Eboh, M. (2011). "Cashless Economic Policy will save Nigeria N192bn - CBN", (Online) Available: http//www.nigerianewsday.com/

Eromosele and Obinna (2012). Represented in Obodo (2013. Journal of Finance and Accounting. Vol. 4 No.7 2012.

Ezumba, S. (2011). "The Transition to a Cashless Nigeria", reinventing Rebuilding LLC, Chronicle", (Online)Available: http://www.allAfrica.com.

Omotunde et al.(2013). Impact of cashless Economy in Nigeria,Greener Journal of Internet, Information and Communication System Vol(1) 